\title{
A Crucial Role of Hepatocyte Nuclear Factor-4 Expression in the Differentiation of Human Ductular Hepatocytes
}

\author{
Tomomi Hakoda, Kazuhide Yamamoto, Ryo Terada, Nobuaki Okano, \\ Noriaki Shimada, Takahiro Suzuki, Motowo Mizuno, and Yasushi Shiratori \\ Department of Medicine and Medical Science, Okayama University Graduate School of Medicine and Dentistry, \\ Okayama, Japan
}

\begin{abstract}
SUMMARY: Ductular structures are suggested to be bipotential progenitor cells that may differentiate into hepatocytes or biliary epithelial cells (BEC). To better understand the differentiation process, we studied the expression of hepatocyte nuclear factor (HNF) in ductular structures. Matured hepatocytes in normal liver expressed HNF-1, HNF-4 $\alpha$, HNF-3 $\beta$, and C/EBP $\alpha$ in the nucleus. Normal BEC expressed HNF-1 but did not express HNF- $4 \alpha$, suggesting an important role of HNF- $4 \alpha$ in maintaining the phenotype of matured hepatocytes. Ductular structures were classified into ductular cells and ductular hepatocytes. Ductular cells showed glandular or bile duct-like appearance and strongly expressed cytokeratin-7. Ductular hepatocytes showed features between BEC and hepatocytes and heterogeneously expressed cytokeratin-7. Both ductular cells and ductular hepatocytes expressed HNF- $4 \alpha$, but the nuclear localization of HNF- $4 \alpha$ was more prominent in ductular hepatocytes. The expression of HNF- $4 \alpha$ mRNA in ductular hepatocytes was demonstrated at the single cell level by laser capture microdissection. Regenerative hepatocytes strongly expressed all HNFs in the nucleus, whereas residual hepatocytes in massive necrosis showed low or cytoplasmic expression. These results suggest that HNF- $4 \alpha$ plays an important role in the differentiation and maintenance of the matured hepatocyte phenotype and that nuclear localization of HNFs is implicated in the accomplishment of their function. (Lab Invest 2003, 83:1395-1402).
\end{abstract}

$T$ he liver is an organ that retains an enormous regenerative capacity, and regeneration occurs when the normal architecture and function are lost after various injuries to the liver (Fausto and Webber, 1994; Michalopoulos and DeFrances, 1997). Three types of cells are suggested to respond to injury: matured hepatocytes, bipotential progenitor cells, and putative periductular stem cells (Sell, 2001). The type of cells involved in the regeneration is dependent on both the type and severity of liver injury. Matured hepatocytes are involved in liver regeneration after mild to moderate hepatocyte loss. In contrast, liver progenitor cells or periductular stem cells are involved in massive liver injury, in which the majority of mature hepatocytes are lost (Demetris et al, 1996; Haque et al, 1996; Roskams et al, 1998; Rubin et al, 1995; Sell, 1998; Theise et al, 1999). Ductular structures or ductular hepatocytes that appear around the portal tract in massive hepatic necrosis are suggested to result from proliferation of bipotential progenitor cells or peri-

DOI: 10.1097/01.LAB.0000092229.93203.57

Received May 24, 2003.

This work was supported by Grant No. 12470122 from the Ministry of Education, Culture, Sports, Science and Technology, Japan.

Address reprint requests to: Dr. K. Yamamoto, Department of Medicine and Medical Science, Okayama University Graduate School of Medicine and Dentistry, 2-5-1, Shikata-cho, Okayama 700-8558, Japan. E-mail: kazuhide@md.okayama-u.ac.jp ductular stem cells. Repopulation of bone marrow stem cells into hepatocytes has been demonstrated recently in animals and humans (Petersen et al, 1999; Theise et al, 2000). Bone marrow-derived stem cells may comprise part of the periductular stem cell population in the liver.

Ductular structures represent the major proliferating cell populations in regenerating liver after massive hepatic necrosis. Ductular structures express the phenotype of both the biliary epithelial cell lineage and hepatocyte lineage. Although it has been hypothesized that ductular structures are derived from bipotential progenitor cells and transform into matured hepatocytes, the transition has not been confirmed in human livers. Recently, the transition from ductular structures into mature hepatocytes was suggested by sequential biopsies in a patient with fulminant hepatitis (FH) who received auxiliary partial orthotopic liver transplantation (Fujita et al, 2000). In that case, ductular structures transformed into matured hepatocytes after several months, although the mechanism of the transition remains unknown.

In the embryo, the processes of liver development and differentiation are controlled by the sequential expression of liver-specific genes. Hepatocyte nuclear factors (HNFs) participate in the expression of liverspecific genes and play an important role in liver development and the functional maturation of hepatocytes (Calkhoven and Ab, 1996; Cereghini, 1996; 
Darlington, 1999; Kuo et al, 1992). If ductular structures are derived from liver progenitor cells and follow the course of differentiation into matured hepatocytes, they may express HNFs as seen in the development of the liver. The expression and role of HNFs in the differentiation of progenitor cells into mature hepatocytes have been studied in animals after treatment with chemical carcinogens or a choline-deficient diet (Bisgaard et al, 1996; Dabeva et al, 1995; Nagy et al, 1994; Rao et al, 1996). It is not known whether ductular structures in the human liver express HNFs during the period of regeneration.

In the present study, the expression of HNFs was examined immunohistochemically in liver with massive hepatic necrosis to clarify their role in liver regeneration and the transition from ductular structures into matured hepatocytes.

\section{Results}

\section{Pathologic Findings}

The pathologic findings of 11 patients are summarized in Table 1. Liver tissues from six deceased patients and four patients who underwent liver transplantation showed massive or submassive hepatic necrosis. One recovered patient showed posthepatitic scarring. In patients with massive hepatic necrosis, a few hepatocytes remained without regeneration. In patients with submassive hepatic necrosis, various numbers of hepatocytes remained with degenerative changes such as cholestasis, fatty change, and ballooning. The remaining hepatocytes with degeneration were designated as "residual hepatocytes." In Case 11 who recovered from $\mathrm{FH}$, regenerative nodules were formed and the hepatocytes were designated as "regenerative hepatocytes."

Ductular structures appeared in liver tissues with massive or submassive hepatic necrosis. We tentatively classified cells with ductular structures into "ductular cells" and "ductular hepatocytes" based on their morphologic features. Ductular cells appear around the portal tract and show glandular or bile duct-like structures, resembling biliary epithelial cells (BEC) (Fig. 1, a and c). Ductular hepatocytes show features between BEC and hepatocytes and were often intermingled with hepatocytes (Fig. 1, b and d). Ductular cells were observed in 10 of 11 patients, and ductular hepatocytes were observed in 5 of 11 patients. Ductular hepatocytes had a tendency to appear in patients in whom liver tissue was obtained at a later time after the onset.

\section{Immunohistochemistry}

The expression patterns of four HNFs in normal and $\mathrm{FH}$ livers are summarized in Table 2. The localization of HNFs was evaluated in the cytoplasm (C), the nucleus $(\mathrm{N})$, or both (NC).

\section{HNF Expression in Normal Livers}

In normal hepatocytes, both HNF-1 and $-4 \alpha$ were expressed exclusively in the nucleus in all cases (Figs. 2 , $a$ and $b$, and $3 a$; Table 2). Both HNF-3 $\beta$ and C/EBP $\alpha$ were also expressed in all cases, but the localization was either in the N or NC pattern (Fig. 2, c and d; Table 2).

In BEC of normal livers, HNF-1 was expressed in the nucleus as in hepatocytes (Fig. 2a). However, HNF-4 $\alpha$ was not expressed in BEC (Fig. 2b), suggesting that $\mathrm{HNF}-4 \alpha$ is an important transcription factor for maintenance of the phenotype of matured hepatocytes. Both HNF-3 $\beta$ and $\mathrm{C} / \mathrm{EBP} \alpha$ were rarely expressed in the nucleus of BEC, but cytoplasmic expression was observed in a few cases.

\section{HNF Expression in FH Livers}

The livers obtained from patients with $\mathrm{FH}$ contain four different compartments including ductular cells, ductular hepatocytes, residual hepatocytes, and regenerative hepatocytes in varying combinations. The HNF expression was evaluated separately in each compartment (Table 2).

Table 1. Clinical and Pathologic Features of Patients

\begin{tabular}{|c|c|c|c|c|c|c|c|c|c|}
\hline Case & Age (yr) & Sex & Cause & $\begin{array}{c}\text { Period after } \\
\text { onset }\end{array}$ & $\begin{array}{l}\text { Histologic } \\
\text { diagnosis }\end{array}$ & $\begin{array}{l}\text { Ductular } \\
\text { cells }\end{array}$ & $\begin{array}{c}\text { Ductular } \\
\text { hepatocytes }\end{array}$ & $\begin{array}{c}\text { Residual } \\
\text { hepatocytes }\end{array}$ & $\begin{array}{l}\text { Regenerative } \\
\text { hepatocytes }\end{array}$ \\
\hline 1 & 66 & $M$ & HBV & 20 days & SMHN & +++ & + & + & - \\
\hline 2 & 38 & $\mathrm{~F}$ & HAV & 19 days & MHN & ++ & - & - & - \\
\hline 3 & 28 & $\mathrm{~F}$ & HBV & 9 days & MHN & +++ & + & + & - \\
\hline 4 & 46 & $\mathrm{~F}$ & HAV & $3 \mathrm{~m}$ & MHN & ++ & - & + & - \\
\hline 5 & 51 & $M$ & DRUG & 40 days & SMHN & ++ & + & + & - \\
\hline 6 & 60 & $\mathrm{M}$ & HBV & 14 days & $\mathrm{MHN}$ & ++ & - & - & - \\
\hline 7 & 29 & $\mathrm{~F}$ & HBV & 16 days & SMHN & ++ & - & + & - \\
\hline 8 & 36 & $\mathrm{~F}$ & HBV & 16 days & MHN & ++ & - & + & - \\
\hline 9 & 44 & $\mathrm{~F}$ & AlH & 54 days & SMHN & + & ++ & + & - \\
\hline 10 & $6(\mathrm{mo})$ & $M$ & Unknown & 14 days & MHN & ++ & - & - & - \\
\hline 11 & 29 & $\mathrm{~F}$ & HBV & $5 \mathrm{~m}$ & PHS & - & ++ & - & +++ \\
\hline
\end{tabular}

HBV, hepatitis B virus; HAV, hepatitis A virus; AlH, autoimmune hepatitis; SMHN, submassive hepatic necrosis; MHN, massive hepatic necrosis; PHS, posthepatitic scarring; -, not present; + , a few present; ++ , moderate number present; +++ , many present. 

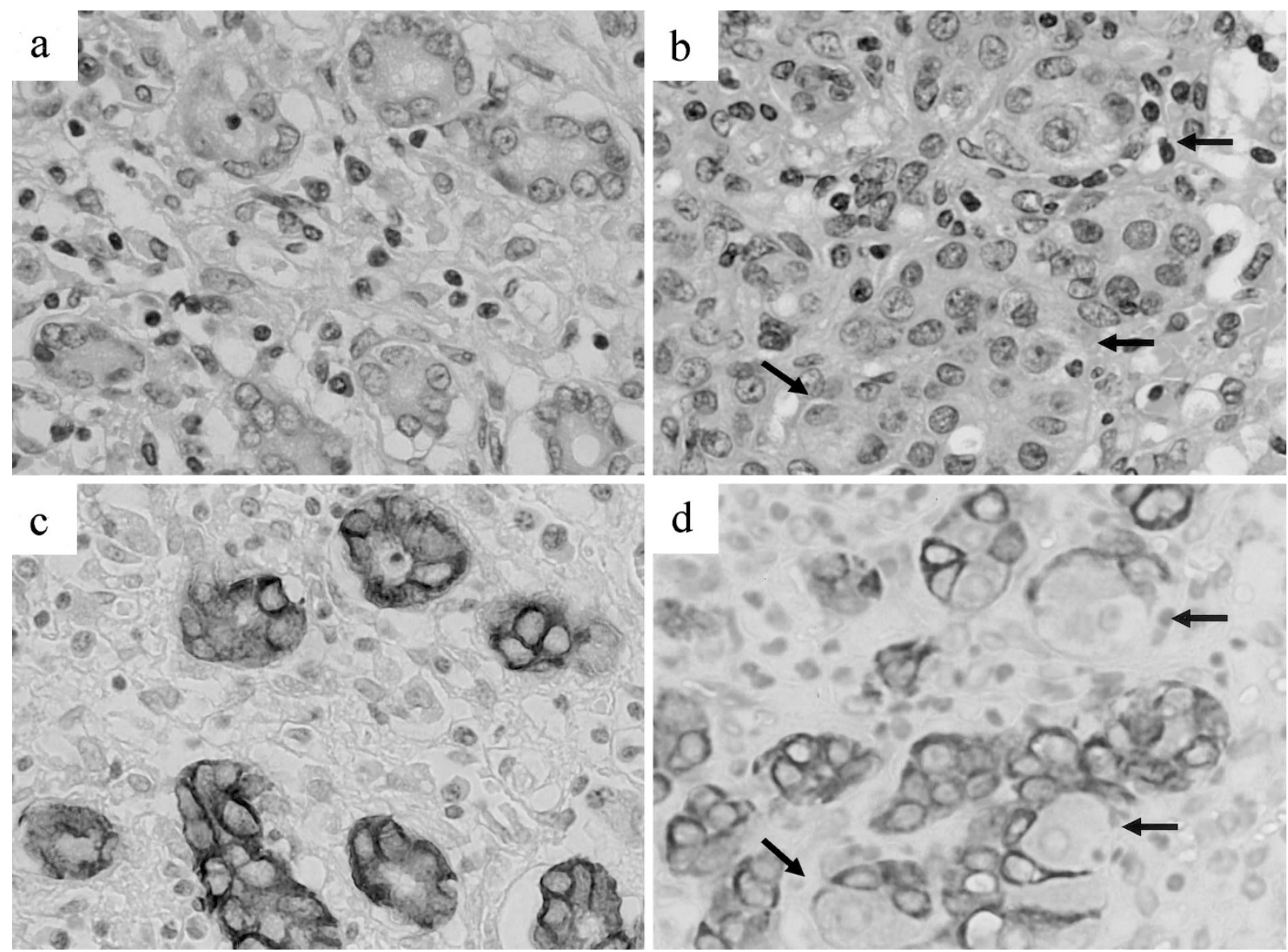

\section{Figure 1.}

Ductular cells and ductular hepatocytes in massive hepatic necrosis. Ductular cells (a and c) appear around the portal tract and show glandular or bile duct-like structures (Case 8 in Table 1). Ductular hepatocytes ( $b$ and $d$ ) show features between biliary epithelial cells (BEC) and hepatocytes and are intermingled with hepatocytes (Case 1 in Table 1). Intermingled hepatocytes show poor cytokeratin-7 (CK-7) staining (arrows indicate identical cells). a and b, hematoxylin and eosin staining; $c$ and $d$, CK-7 staining; $\times 500$.

Table 2. HNF Expression in Normal Livers and FH

\begin{tabular}{|c|c|c|c|c|c|c|}
\hline & \multicolumn{2}{|c|}{ Normal liver } & \multicolumn{4}{|c|}{ Fulminant hepatitis } \\
\hline & $\begin{array}{c}\text { Biliary } \\
\text { epithelial }\end{array}$ & Hepatocytes & $\begin{array}{l}\text { Ductular } \\
\text { cells }\end{array}$ & $\begin{array}{l}\text { Ductular } \\
\text { hepatocyte }\end{array}$ & $\begin{array}{l}\text { Residual } \\
\text { hepatocytes }\end{array}$ & $\begin{array}{l}\text { Regenerative } \\
\text { hepatocytes }\end{array}$ \\
\hline \multicolumn{7}{|l|}{ HNF-1 } \\
\hline Nuclear & $9 / 9$ & $9 / 9$ & $8 / 10$ & $4 / 5$ & $0 / 6$ & $1 / 1$ \\
\hline Cytoplasmic & $1 / 9$ & $5 / 9$ & $5 / 10$ & $0 / 5$ & $3 / 6$ & $0 / 1$ \\
\hline \multicolumn{7}{|l|}{ HNF- $4 \alpha$} \\
\hline Nuclear & $0 / 9$ & $9 / 9$ & $7 / 10$ & $5 / 5$ & $1 / 6$ & $1 / 1$ \\
\hline Cytoplasmic & $0 / 9$ & $1 / 9$ & $6 / 10$ & $1 / 5$ & $2 / 6$ & $0 / 1$ \\
\hline \multicolumn{7}{|l|}{ HNF-3 $\beta$} \\
\hline Nuclear & $3 / 9$ & $6 / 9$ & $1 / 10$ & $1 / 5$ & $0 / 6$ & $1 / 1$ \\
\hline Cytoplasmic & $3 / 9$ & $6 / 9$ & $6 / 10$ & $2 / 5$ & $2 / 6$ & $0 / 1$ \\
\hline \multicolumn{7}{|l|}{$\mathrm{C} / \mathrm{EBP} \alpha$} \\
\hline Nuclear & $0 / 9$ & $2 / 9$ & $0 / 10$ & $1 / 5$ & $0 / 6$ & $1 / 1$ \\
\hline Cytoplasmic & $2 / 9$ & $7 / 9$ & $3 / 10$ & $1 / 5$ & $2 / 6$ & $0 / 1$ \\
\hline AFP & - & - & + & + & - & - \\
\hline CK-7 & + & - & + & $+1-$ & - & - \\
\hline
\end{tabular}

In ductular cells, HNF-1 was expressed in the nucleus or cytoplasm (Fig. 2e). HNF-4 $\alpha$ was expressed mostly in the cytoplasmic pattern (Figs. $2 f$ and $3 b)$. HNF-3 $\beta$ and $\mathrm{C} / \mathrm{EBP} \alpha$ were expressed in the cytoplasmic pattern in some cases (Fig. 2, g and h). 


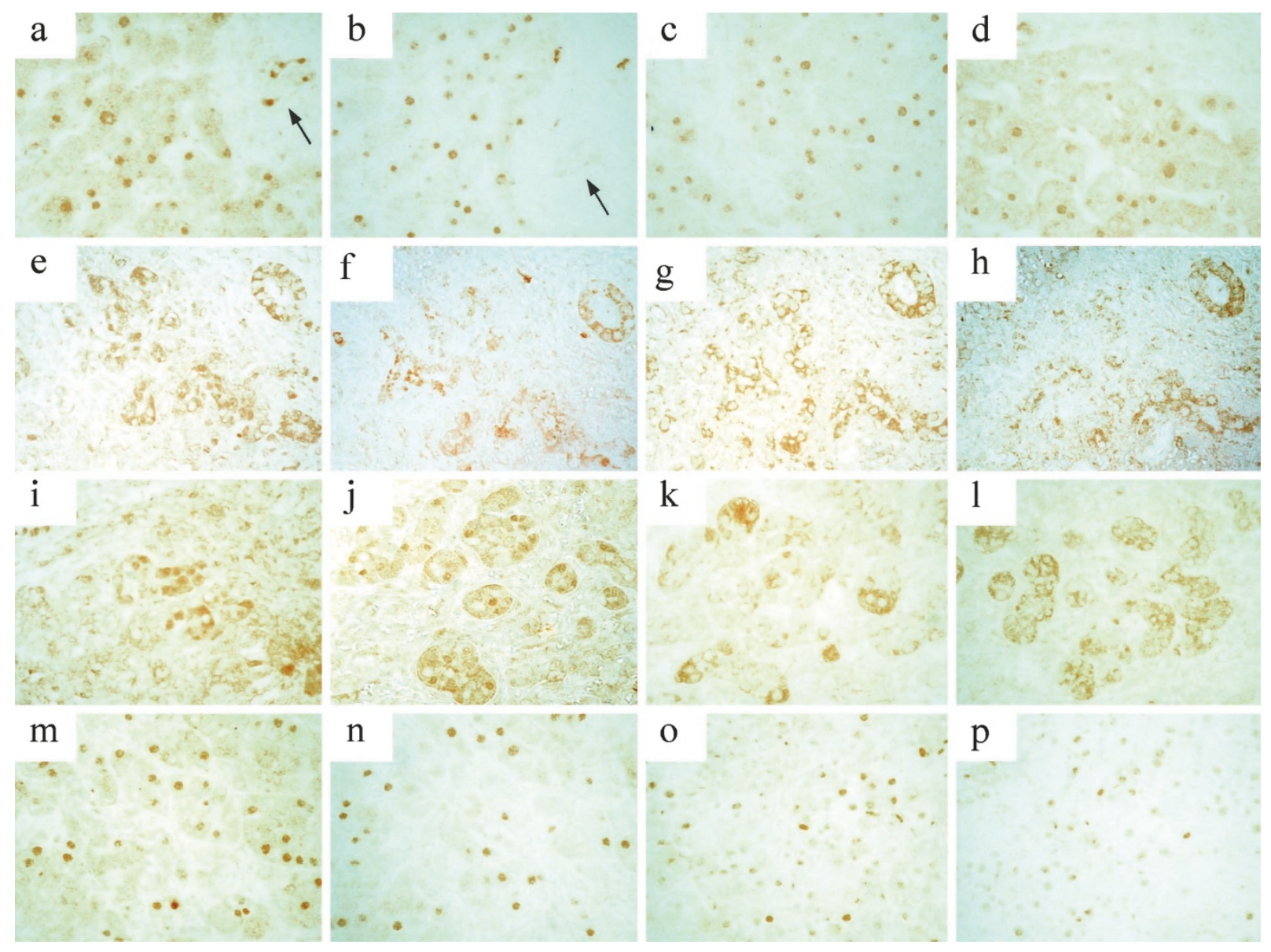

Figure 2.

Expression of hepatocyte nuclear factors (HNFs) in normal liver (a to d), ductular cells (e to h), ductular hepatocytes (i to l), and regenerative hepatocytes ( $m$ to $p$ ). Each column shows HNF-1 (a, e, i, and $\mathrm{m}), \operatorname{HNF}-4 \alpha(\mathrm{b}, \mathrm{f}, \mathrm{j}$, and $\mathrm{n}), \operatorname{HNF}-3 \beta(\mathrm{c}, \mathrm{g}, \mathrm{k}$, and $\mathrm{o})$, and $\mathrm{C} / \mathrm{EBP} \alpha(\mathrm{d}, \mathrm{h}, \mathrm{I}$, and $\mathrm{p})$, respectively. All HNFs are localized in the nucleus of normal ( $a$ to $d$ ) and regenerative hepatocytes ( $m$ to $p$ ). Although HNF-1 is expressed in the nucleus of normal BEC (a, arrow), HNF-4a is not expressed (b, arrow). HNFs are mostly expressed in the cytoplasm of ductular cells (e to h), whereas HNF-1 and HNF-4 $\alpha$ are expressed in the cytoplasm and nucleus of ductular hepatocytes (i and j). $\times 135$.

In ductular hepatocytes, HNF-1 was expressed in the nucleus (Fig. 2i). HNF-4 $\alpha$ was also expressed in the $N$ pattern (Figs. 2j and 3c). Both HNF-3 $\beta$ and C/EBP $\alpha$ were expressed in the cytoplasm (Fig. 2, $\mathrm{k}$ and I). The nuclear localization of both HNF-1 and $-4 \alpha$ suggests that the HNF expression pattern of ductular hepatocytes resembles that of matured hepatocytes and that HNF- $4 \alpha$ is important for the differentiation into matured hepatocytes.

Residual hepatocytes remaining in massive necrotic tissues showed no expression or cytoplasmic expression of HNFs (Table 2). The expressions of both HNF-1 and $-4 \alpha$ were mostly restricted to the cytoplasm. The localization of HNFs into the nucleus seemed to be disturbed in residual hepatocytes.

Regenerative hepatocytes were noted only in Case 11, who recovered from FH. Regenerative hepatocytes expressed all HNFs, which were localized at the nucleus (Fig. 2, $m$ to p).

\section{Expression of cytokeratin-7 (CK-7), Glycogen, $\alpha$-fetoprotein (AFP), and CD34}

CK-7 was used as a marker of BEC. BEC in the normal liver was strongly positive for CK-7. Ductular cells were also positive for CK-7 (Fig. 1c). Most ductular hepatocytes were positive, but intermingled hepatocytes were less strongly positive or negative for CK-7 (Fig. 1d). Residual hepatocytes and regenerative hepatocytes were negative for CK-7.

The expression of HNF- $4 \alpha$ and glycogen in ductular hepatocytes was studied with double staining (Fig. 3d). HNF- $4 \alpha$ was stained brown and localized at the nucleus and cytoplasm. Glycogen was stained purple and localized in the cytoplasm. Some HNF- $4 \alpha$-positive cells were positive for glycogen. The expression of HNF- $4 \alpha$ and AFP was studied in serial sections. HNF$4 \alpha$-positive cells were also positive for AFP.

CD34 was expressed in endothelial cells. Ductular cells, ductular hepatocytes, and regenerative hepatocytes were negative for CD34 expression (data not shown)

\section{Electron Microscopy}

Ductular cells and ductular hepatocytes showed glandular appearance and hepatocytes were intermingled. The glandular structures were lined by basement membrane (Fig. 4). 



\section{Figure 3.}

HNF-4 $\alpha$ expression in ductular cells and ductular hepatocytes. a, HNF- $4 \alpha$ is localized in the cytoplasm of ductular cells. b, HNF- $4 \alpha$ is localized in the cytoplasm and nucleus of ductular hepatocytes. c, $\alpha$-fetoprotein (AFP) is expressed in HNF- $4 \alpha$-positive ductular hepatocytes. A consecutive section of b. d, Double staining of HNF- $4 \alpha$ and glycogen (PAS staining). HNF- $4 \alpha$-positive cells are also positive for glycogen (arrows). $\times 310$.

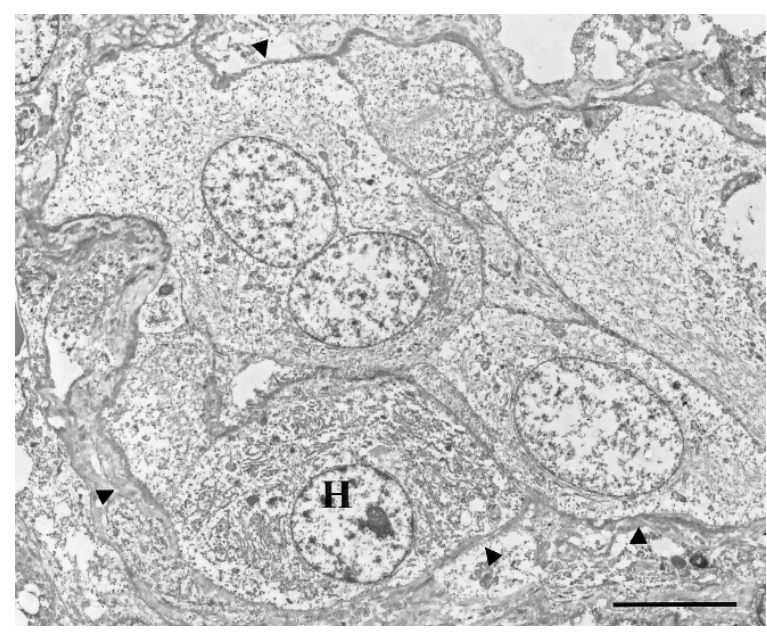

\section{Figure 4.}

Electron micrograph of ductular hepatocytes. A hepatocyte intermingled with ductular hepatocytes $(H)$. The glandular structure is lined by basement membrane (arrowheads). Bar $=10 \mu \mathrm{m}$.

\section{Laser Capture Microdissection (LCM) and RT-PCR}

The expression of the HNF- $4 \alpha$ message was studied at the single-cell level using LCM and RT-PCR. Mes- sage analysis was positive for PCR products in ductular cells, ductular hepatocytes, and matured hepatocytes but negative for PCR products in BEC (Fig. 5).
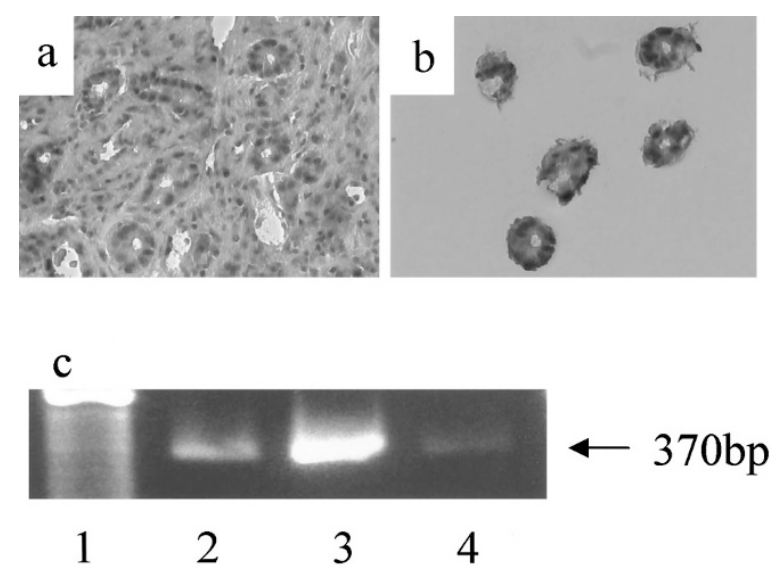

Figure 5.

Laser capture microdissection (LCM) and message analysis. Ductular cells are selectively laser captured. Before LCM (a) and captured ductular cells (b). c, RT-PCR of HNF-4 $\alpha$ mRNA. Lane 1, 25-bp ladder marker; lane 2, total liver homogenate from massive hepatic necrosis; lane 3 , total liver homogenate from normal liver; lane 4, laser-captured ductular cells. 


\section{Discussion}

Hepatoblasts differentiate into mature hepatocytes or BEC during the development of the liver. The differentiation is regulated by cell type-specific gene expression, which is controlled by distinct sets of transcription factors including HNFs (Cereghini, 1996; Darlington, 1999). The present study showed that normal human hepatocytes express HNF- $4 \alpha$, whereas $\mathrm{BEC}$ do not, suggesting that $\mathrm{HNF}-4 \alpha$ plays a crucial role in the maintenance of normal hepatocyte function. This is consistent with previous findings in the rat liver, in which the expression of HNF-4 determines differentiation into matured hepatocytes ( $\mathrm{Li}$ et al, 2000; Runge et al, 1998; Spath and Weiss, 1997). However, in contrast to the rat liver, HNF -1 and $-3 \beta$ are expressed even in normal human BEC.

It was proposed that ductular structures appearing in massive hepatic necrosis are derived from bipotential hepatic progenitor cells and may proliferate and differentiate into matured hepatocytes, replacing parenchymal cells lost by massive hepatic necrosis (Demetris et al, 1996; Haque et al, 1996; Roskams et al, 1998; Rubin et al, 1995; Sell, 1998, 2001; Theise et al, 1999). We were interested in examining whether we could observe the expression of HNFs similar to that observed in normal liver development, if ductular structures are bipotential progenitor cells and develop into matured hepatocytes (Li et al, 2000; Runge et al, 1998; Spath and Weiss, 1997). As summarized in Table 2, both ductular cells and ductular hepatocytes expressed HNF- $4 \alpha$, suggesting that ductular structures are cell populations committed to the hepatocyte lineage.

We separated ductular structures into two compartments, such as ductular cells and ductular hepatocytes, from the morphologic features and compared the phenotypes between them. Ductular cells appear during the early phase after massive hepatic necrosis and show a BEC-like phenotype as demonstrated by strong expression of CK-7 (Fig. 1b). On the other hand, ductular hepatocytes are observed during the late stage and show morphologic features between BEC and mature hepatocytes. CK-7 expression in ductular hepatocytes is weak and heterogeneous compared with that in ductular cells (Fig. 1d). Both ductular cells and ductular hepatocytes express HNF$4 \alpha$, but the nuclear localization is more prominent in ductular hepatocytes than in ductular cells, suggesting ductular hepatocytes belong to differentiated cell populations.

The biologic characteristics of ductular structures resemble those of oval cells in animals, which appear under the treatment of chemical carcinogens or choline-deficient diet and develop into matured hepatocytes when hepatocytes are disturbed to proliferate (Bisgaard et al, 1996; Dabeva et al, 1995; Nagy et al, 1994; Rao et al, 1996). Oval cells also express HNFs such as HNF-1, HNF-3, C/EBP, and DBP during the process of differentiation into matured hepatocytes. However, there are some differences in the expression pattern between human ductular structures and rat oval cells. The expression of HNF-4 in oval cells is at a low level in contrast to that in the basophilic foci, suggesting that HNF-4 is not expressed in oval cells until final commitment to the differentiation to matured hepatocytes. The expression of HNF-3 $\beta$ and $\mathrm{C} / \mathrm{EBP} \alpha$ is at a low frequency in human ductular structures compared with in rat oval cells. These results suggest that ductular cells or ductular hepatocytes in the human liver may be cell populations comparable with oval cells in the rat liver but may not be entirely the same.

Two types of cells are suspected as the origin of ductular cells in human or oval cells in animals. One is the bipotential progenitor cell residing in the liver. The existence of uncommitted progenitor cells in the liver and pancreas has been suggested in experimental models (Rao et al, 1989; Sell, 1998). The other is the stem cell derived from the bone marrow (Petersen et al, 1999; Theise et al, 2000). Although migration and transdifferentiation of hematopoietic stem cells have been shown in various organs including the liver, the plasticity of hematopoietic stem cells is still controversial (Wagers et al, 2002). The type and severity of tissue injury may decide the extent of migration of hematopoietic stem cells, and the mechanism needs to be explored in the future.

Transcription factors are generally controlled at two different levels, namely concentration and activity, each of which can be modulated in a variety of ways (Cereghini, 1996; Darlington, 1999). It is interesting to note that the level of the HNF expression in residual hepatocytes was low compared with that in ductular hepatocytes or regenerative hepatocytes. The low HNF expression may suggest that the function of residual hepatocytes is impaired and that regenerative capacity may also be disturbed. This phenomenon is similar to the experimental condition in rats treated with 2-acetylaminofluorein in which oval cells proliferate and differentiate into hepatocytes because of the disturbed proliferation of pre-existing mature hepatocytes (Bisgaard et al, 1996; Nagy et al, 1994; Sell, 1998). On the other hand, the activity of a transcription factor is often regulated by phosphorylation, which may affect functions of HNFs, eg, nuclear localization, DNA binding, and trans-activation. In some ductular cells and residual hepatocytes, HNFs are expressed but are detained in the cytoplasm. The impaired nuclear localization may explain the immature phenotype of ductular cells. It remains to be clarified what mechanism controls nuclear localization of HNFs in ductular cells or residual hepatocytes.

Liver regeneration occurs at different cell levels dependent on the type and severity of liver injury. In massive or submassive hepatic necrosis, matured hepatocytes are lost and bipotential progenitor cells or stem cells must proliferate and replace the lost hepatocyte mass. In contrast to the proliferation of matured hepatocytes in moderate liver injury, it will take longer periods of time for liver progenitor cells to proliferate and differentiate. Furthermore, the remodeling of a crashed sinusoidal framework is an important step in liver regeneration after massive hepatic necrosis. This 
may explain one of the reasons for the poor prognosis of patients with massive hepatic necrosis. If sufficient liver support is provided, the progenitor or stem cells will proliferate and differentiate into matured hepatocytes and replace the lost hepatocyte mass as shown in patients treated with auxiliary partial orthotopic liver transplantation (Fujita et al, 2000).

Although HNFs may play an important role in the differentiation of progenitor cells and their commitment to the hepatocyte lineage, the mechanism that controls the expression of each HNF at the appropriate time of regeneration needs to be clarified. Molecular manipulation such as gene targeting for immature progenitor cells to hasten proliferation and differentiation may provide a future therapeutic approach for the treatment of patients with $\mathrm{FH}$.

In conclusion, the present study demonstrated that the ductular structures that appeared after massive hepatic necrosis were liver progenitor cells committed to the hepatocyte lineage and that HNF- $4 \alpha$ expression is a crucial step for the differentiation into matured hepatocytes.

\section{Materials and Methods}

\section{Patients}

Five normal livers and 11 livers from patients with $\mathrm{FH}$ were enrolled in the study. The study protocol was approved by the Institution's Human Research Committee. The clinical features of the 11 patients with $\mathrm{FH}$ are summarized in Table 1. Six patients died, four received transplants from living related donors, and one recovered. The time from the onset of hepatitis to the examination of liver tissues is also listed in Table 1. Normal livers were obtained from donors of livingrelated liver transplants for the study of liver disease.

\section{Liver Tissues}

Liver tissues were obtained at autopsy or liver transplantation in $10 \mathrm{FH}$ patients and by liver biopsy in 1 recovered patient. For immunohistochemical study, tissues were fixed in buffered $10 \%$ formalin and embedded in paraffin. Four-micrometer sections were prepared and processed for staining with hematoxylin and eosin, silver impregnation, Azan, and periodic acid Schiff (PAS) after diastase digestion. For laser microdissection, liver tissues were embedded in OCT compound and frozen in acetone chilled with dry ice.

\section{Antibodies}

Antibodies specific for HNFs were obtained from Santa Cruz Biotechnology, Inc. (Santa Cruz, California) (HNF-1: sc-8986; HNF-3 $\beta$ : sc-6554; HNF-4 $\alpha$ : sc8987; and C/EBP: sc-9314). CK-7 was used as a marker specific for BEC, and anti-CK-7 mAb was obtained from Dako Japan Company, Ltd. (OV-TL 12/30; Kyoto, Japan). Antibodies for AFP and CD34 were obtained from Dako (A 001) and Nichirei Corp. (NU-4A1; Tokyo, Japan), respectively.

\section{Immunohistochemistry}

Four-micrometer sections were cut and deparaffinized. For HNF-1 and $-4 \alpha$ staining, sections were pretreated at $100^{\circ} \mathrm{C}$ in a microwave oven in $0.1 \mathrm{M}$ sodium citrate buffer for 10 minutes. For HNF-3 $\beta$ and $\mathrm{C} / \mathrm{EBP} \alpha$ staining, sections were pretreated with $0.4 \%$ pepsin solution (pepsin A; Sigma-Aldrich Japan K.K., Tokyo, Japan) at $37^{\circ} \mathrm{C}$ for 20 minutes. For CK-7 staining, sections were treated with $0.05 \%$ protease (type XXV; Sigma-Aldrich Japan K.K.) in a $50 \mathrm{~mm}$ Tris- $\mathrm{HCl}$ solution for 10 minutes at room temperature. AFP and CD34 were stained without pretreatment. Then the sections were incubated with each mAb overnight at $4^{\circ} \mathrm{C}$ after nonspecific binding was blocked with Dako protein block. Intrinsic peroxidase activity was blocked in a methanol solution containing $0.3 \%$ hydrogen peroxide, and the sections were treated with ENVISION/horseradish peroxidase (Dako). Finally, the sections were immersed in 3,3'diaminobenzidine, and nuclear staining was performed with $3 \%$ methyl green. For control experiments the first $\mathrm{mAb}$ was omitted from the reaction process.

The localization of HNFs was judged as cytoplasmic, nuclear, or both. The expression was analyzed in different cellular compartments such as normal hepatocytes and BEC, ductular cells, ductular hepatocytes, residual hepatocytes remaining in submassive hepatic necrosis, and regenerative hepatocytes.

Comparative staining was performed to demonstrate that HNF- $4 \alpha$-positive cells express hepatocytespecific genes. First, double staining of HNF- $4 \alpha$ and PAS was performed. A section was stained for $\mathrm{HNF}-4 \alpha$ and then stained with PAS for glycogen. Second, HNF- $4 \alpha$ and AFP were stained in serial sections.

\section{Electron Microscopy}

Tissues were fixed in $2 \%$ glutaraldehyde in $0.1 \mathrm{M}$ phosphate buffer $(\mathrm{pH} 7.4)$ for 2 hours and subsequently fixed in $1 \%$ osmium tetroxide for 1 hour. Tissues were embedded in Epon. Ultrathin sections cut with an ultramicrotome (Sorvall, Newtown, Connecticut) were stained with uranyl acetate and lead citrate. Observations were performed with a transmission microscope (H-7100; Hitachi, Tokyo, Japan).

\section{LCM and RT-PCR}

Ten-micrometer frozen sections were prepared from normal liver and $\mathrm{FH}$ livers, fixed in $70 \%$ ethanol solution, and stained with hematoxylin and eosin. BEC, hepatocytes, and ductular hepatocytes were selectively picked up under LCM (Arcturus Engineering, Inc., California). At least 1000 cells were collected in each fraction. Total RNA was collected using the total RNA Microprep kit (Stratagene, La Jolla, California) and cDNA was prepared using oligo dT primer (SuperScript; Life Technologies, Gaithersburg, Maryland). A 1- $\mu$ l aliquot of the cDNA reaction product was mixed with primer specific for HNF- $4 \alpha$ (sense: $5^{\prime}-$ 
CTGCTCGGAGCCACAAAGAGATCCATG-3'; antisense: 5'-ATCATCTGCCACGTGATGCTCTGCA-3'). PCR was performed with $100 \mathrm{nmol}$ dNTP and $5 \mathrm{U} / \mu \mathrm{l}$ AmpliTaq Gold (Perkin Elmer Japan Company, Chiba, Japan) for 40 cycles $\left(95^{\circ} \mathrm{C}\right.$ for 30 seconds, $58^{\circ} \mathrm{C}$ for 30 seconds, $72^{\circ} \mathrm{C}$ for 1 minute) and a final extension $\left(72^{\circ} \mathrm{C}\right.$ for 7 minutes) in a Perkin-Elmer/Cetus thermocycler (Perkin Elmer Japan Company). The PCR products $(4 \mu \mathrm{l})$ were loaded on a $2 \%$ agarose gel with ethidium bromide and visualized by UV fluorescence.

\section{Acknowledgements}

We thank Ms. Kazumi Inada in our department and Mr. Haruo Urata and Ms. Masumi Furutani, Central Research Laboratory, for technical assistance.

\section{References}

Bisgaard HC, Nagy P, Santoni-Rugiu E, and Thorgeirsson SS (1996). Proliferation, apoptosis, and induction of hepatic transcription factors are characteristics of the early response of biliary epithelial (oval) cells to chemical carcinogens. Hepatology 23:62-70.

Calkhoven CF and Ab G (1996). Multiple steps in the regulation of transcription-factor level and activity. Biochem $\mathrm{J}$ 317:329-342.

Cereghini S (1996). Liver-enriched transcription factors and hepatocyte differentiation. FASEB J 10:267-282.

Dabeva MD, Hurston E, and Sharitz DA (1995). Transcription factor and liver-specific mRNA expression in facultative epithelial progenitor cells of liver and pancreas. Am J Pathol 147:1633-1648.

Darlington GJ (1999). Molecular mechanisms of liver development and differentiation. Curr Opin Cell Biol 11:678-682.

Demetris AJ, Seaberg EC, Wennerberg A, lonellie J, and Michalopoulos G (1996). Ductular reaction after submassive necrosis in humans: Special emphasis on analysis of ductular hepatocytes. Am J Pathol 149:439-448.

Fausto $\mathrm{N}$ and Webber EM (1994). Liver regeneration, 3rd ed. In: Arias IM, Boyer JL, Fausto N, Jakoby WB, Schachter DA, Shafritz DA, editors. The liver: Biology and pathobiology. New York: Raven Press, Ltd., 1059-1084.

Fujita M, Furukawa H, Hattori M, Todo S, Ishida $\mathrm{Y}$, and Nagashima K (2000). Sequential observation of liver cell regeneration after massive hepatic necrosis in auxiliary partial orthotopic liver transplantation. Mod Pathol 13:152-157.

Haque S, Haruna Y, Saito K, Nalesnik MA, Atillasoy E, Thung SN, and Gerber MA (1996). Identification of bipotential progenitor cells in human liver regeneration. Lab Invest 75:699705.

Kuo CJ, Conley PB, Chen L, Sladek FM, Darnell JE Jr, and Crabtree GR (1992). A transcriptional hierarchy involved in mammalian cell-type specification. Nature 355:457-461.
Li J, Ning G, and Duncan SA (2000). Mammalian hepatocyte differentiation requires the transcription factor HNF-4alpha. Genes Dev 14:464-474.

Michalopoulos GK and DeFrances MC (1997). Liver regeneration. Science 276:60-66.

Nagy P, Bisgaard HC, and Thorgeirsson SS (1994). Expression of hepatic transcription factors during liver development and oval cell differentiation. J Cell Biol 126:223-233.

Petersen BE, Bowen WC, Patrene KD, Mars WM, Sullivan AK, Murase N, Boggs SS, Greenberger JS, and Goff JP (1999). Bone marrow as a potential source of hepatic oval cells. Science 284:1168-1170.

Rao MS, Dwivedi RS, Yeldandi AV, Subbarao V, Tan X, Usman MI, Thangada S, Nemali MR, Kumar S, Scarpelli DG, and Reddy JK (1989). Role of periductal epithelial cells of the adult rat pancreas in pancreatic hepatocyte lineage. Am J Pathol 134:1069-1086.

Rao MS, Yukawa M, Omori M, Thorgeirsson SS, and Reddy JK (1996). Expression of transcription factors and stem cell factor precedes hepatocyte differentiation in rat pancreas. Gene Expr 6:15-22.

Roskams T, De Vos R, Van Eyken P, Myazaki H, Van Damme B, and Desmet V (1998). Hepatic OV-6 expression in human liver disease and rat experiments: Evidence for hepatic progenitor cells in man. J Hepatol 29:455-463.

Rubin EM, Martin AA, Thung SN, and Gerber MA (1995). Morphometric and immunohistochemical characterization of human liver regeneration. Am J Pathol 147:397-404.

Runge D, Runge DM, Drenning SD, Bowen WC Jr, Grandis JR, and Michalopoulos GK (1998). Growth and differentiation of rat hepatocytes: Changes in transcription factors HNF-3, HNF-4, STAT-3, and STAT-5. Biochem Biophys Res Commun 250:762-768.

Sell S (1998). Comparison of liver progenitor cells in human atypical ductular reactions with those seen in experimental models of liver injury. Hepatology 27:317-331.

Sell S (2001). Heterogeneity and plasticity of hepatocyte lineage cells. Hepatology 33:738-750.

Spath GF and Weiss MC (1997). Hepatocyte nuclear factor 4 expression overcomes repression of the hepatic phenotype in dedifferentiated hepatoma cells. Mol Cell Biol 17:19131922.

Theise ND, Nimmakayalu M, Gardner R, Illei PB, Morgan G, Teperman L, Henegariu O, and Krause DS (2000). Liver from bone marrow in humans. Hepatology 32:11-16.

Theise ND, Saxena R, Portmann BC, Thung SN, Yee H, Chiriboga L, Kumar A, and Crawford JM (1999). The canals of Hering and hepatic stem cells in humans. Hepatology 30 : 1425-1433.

Wagers AJ, Sherwood RI, Christensen JL, and Weissman IL (2002). Little evidence for developmental plasticity of adult hematopoietic stem cells. Science 297:2256-2259. 